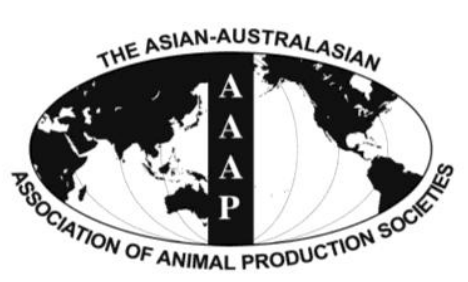

Open Access

Asian Australas. J. Anim. Sci.

Vol. 27 , No. 7 : 1003-1012 July 2014

http://dx.doi.org/10.5713/ajas.2013.13538

pISSN 1011-2367 elSSN 1976-5517

\title{
Comparison of Methodologies to Quantify Phytate Phosphorus in Diets Containing Phytase and Excreta from Broilers
}

\author{
L. de P. Naves*, P. B. Rodrigues, A. G. Bertechini, A. D. Corrêa ${ }^{1}$, D. H. de Oliveira, \\ E. C. de Oliveira, W. F. Duarte ${ }^{2}$, and M. R. R. da Cunha ${ }^{3}$ \\ Animal Science Department, Federal University of Lavras (UFLA), Lavras, Minas Gerais, 37200-000, Brazil
}

\begin{abstract}
The use of a suitable methodology to quantify the phytate phosphorus $\left(\mathrm{P}_{\text {phy }}\right)$ content in both the feed and the excreta from broilers is required to enable accurate calculation of the catalytic efficiency of the phytase supplemented in the feed. This study was conducted to compare 2 analytical methodologies (colorimetry and also high-performance liquid chromatography with a refractive index detector) in order to calculate the phytase efficiency by utilizing the results from the methodology that was shown to be the most appropriate. One hundred and twenty broilers were distributed in a $(4+1) \times 2$ factorial arrangement, corresponding to 4 diets that were equally deficient in P supplemented with increasing levels of phytase $(0,750,1,500$, and 2,250 units of phytase activity - FTU - per kg of feed) plus 1 positive control diet without phytase, supplied to male and female birds. The result indicated that the colorimetric methodology with an extraction ratio of 1:20 (mass of sample in g:volume of the solvent extractor in $\mathrm{mL}$ ) was shown to be the most adequate. There was no interaction between the phytase level and the sex of the broilers ( $p>0.05)$. Males consumed $12 \%$ more $P_{\text {phy }}$ than did females $(p<0.01)$, but the sex of the broilers did not affect $(p>0.05)$ the excretion and retention coefficient of $P_{\text {phy. }}$ The increase in the phytase level of the diet reduced (linear, $\mathrm{p}<0.01$ ) the $\mathrm{P}_{\text {phy }}$ excretion. The greatest $\mathrm{P}_{\text {phy }}$ retention was estimated at $87.85 \%$ when the diet contained $1,950 \mathrm{FTU} / \mathrm{kg}(\mathrm{p}<0.01)$, indicating that it is possible to reduce the inorganic $\mathrm{P}$ in the formulation at an amount equivalent to $87.85 \%$ of the $\mathrm{P}_{\text {phy }}$ content present in the feed, which, in this research, corresponds to a decrease in $2.86 \mathrm{~g}$ of P/kg of the feed. (Key Words: Broiler, Myo-inositol Phosphate, Phosphorus, Phytase, Phytate, Phytic Acid)
\end{abstract}

\section{INTRODUCTION}

Although the economic and environmental benefits obtained through the use of phytase in broiler diets are reported in the literature (Nagata et al., 2011; Santos et al., 2011a,b; Gomide et al., 2012), its catalytic efficiency to make the phytate phosphorus $\left(\mathrm{P}_{\text {phy }}\right)$ of the feed available is not yet well established, and, according to Angel et al.

\footnotetext{
* Corresponding Author: Luciana de Paula Naves. Tel: +55-353829-1691, Fax: +55-35-3829-1231, E-mail: luciana.naves@ hotmail.com

${ }^{1}$ Chemistry Department, UFLA, Lavras, Minas Gerais, 37200000, Brazil.

${ }^{2}$ Biology Department, UFLA, Lavras, Minas Gerais, 37200-000, Brazil.

${ }^{3}$ Chromatography Laboratory, Ezequiel Dias Foundation, Belo Horizonte, Minas Gerais, 30510-010, Brazil.

Submitted Aug. 29, 2013; Revised Dec. 10, 2013; Accepted Jan. 24, 2014
}

(2002), this should be done while considering the $\mathrm{P}_{\text {phy }}$ concentration in both the feed and the excreta. Among the analytical methods used for the phytate determination, those that utilize colorimetric and refraction principles stand out (Wu et al., 2009). However, these methodologies have not yet been compared with each other for samples of feed and excreta. This comparison is important because the use of an inappropriate analytical methodology might lead to misinterpretations of the phytase efficiency.

The colorimetric method is based on a reaction between the ferric ion $\left(\mathrm{Fe}^{3+}\right)$ and the sulfosalicylic acid (wade reagent $[\mathrm{WR}]$ ) with the formation of a complex that can be spectrophotometrically monitored at $500 \mathrm{~nm}$. In the presence of phytate, $\mathrm{Fe}^{3+}$ binds preferentially to $\mathrm{P}_{\text {phy }}$, reducing the color intensity of WR. However, as the $\mathrm{Fe}^{3+}$ does not discriminate between the $\mathrm{P}_{\text {phy }}$ or the inorganic $\mathrm{P}$ $\left(\mathrm{P}_{\text {inorg }}\right)$ present in the sample, it is necessary that, before the colorimetric dosing, the sample go through an anion 
exchange resin to separate $\mathrm{P}_{\text {phy }}$ from $\mathrm{P}_{\text {inorg }}$ (Latta and Eskin, 1980). After the correlation with a standard curve of phytic acid $\left(\mathrm{IP}_{6}\right)$, the result obtained is multiplied by 0.282 to express the content of $\mathrm{P}_{\text {phy }}$ in the sample because this constant corresponds to the molar ratio of $\mathrm{P}$ in the $\mathrm{IP}_{6}$ molecule (Angel et al., 2002). However, it is necessary to assess whether this methodology overestimates the $\mathrm{P}_{\mathrm{phy}}$ in samples containing phosphate esters with fewer than six phosphate groups, which is expected in excreta from broilers fed diets with phytase because according to Greiner et al. (2002), the products of the enzyme degradation of $\mathrm{IP}_{6}$ can include different phosphorylation degrees of the myoinositol ( $\left(\mathrm{IP}_{5}\right.$ to $\left.\mathrm{IP}_{1}\right)$. In contrast, the high-performance liquid chromatography with a refractive index detector (HPLC-IR) discriminated the fractions from $\mathrm{IP}_{3}$ to $\mathrm{IP}_{6}$ in rice bran treated with phytase (Cúneo et al., 2000), arousing the interest in evaluating it in experiments with broilers.

Thus, the objectives of this study were to select the most adequate methodology for the determination of the $\mathrm{P}_{\text {phy }}$ content in both feed and excreta from broilers, to calculate the supplementation level of phytase in which there is the highest retention coefficient of $\mathrm{P}_{\text {phy }}$ and to estimate the $\mathrm{P}$ concentration value that can be reduced in the feed formulation when this level of phytase is used.

\section{MATERIALS AND METHODS}

\section{Experimental materials and procedures}

One metabolism experiment was conducted in Lavras, state of Minas Gerais, Brazil $\left(21^{\circ} 13^{\prime} 52^{\prime \prime}\right.$ S; $\left.44^{\circ} 58^{\prime} 16^{\prime \prime} \mathrm{W}\right)$, with broiler chickens in the period from 15 to 28 days of age to compare two analytical methodologies employed to quantify the content of $\mathrm{P}_{\text {phy }}$ in both the feeds and excreta from birds and to determine the catalytic efficiency of the phytase supplemented in the diet by utilizing the results from the methodology that was shown to be the most appropriate.

All the experimental procedures adopted were approved by the Committee of Ethics in the Use of Animals (protocol code. 004/11). The experiment was conducted in a completely randomized design, distributed in a $(4+1) \times 2$ factorial arrangement, corresponding to 4 diets equally deficient in available $\mathrm{P}\left(\mathrm{P}_{\mathrm{av}}\right)$ supplemented with increasing levels of phytase $(0,750,1,500$, and 2,250 units of phytase activity - FTU - per kg of feed) plus 1 positive control diet without phytase, formulated according to Rostagno et al. (2005). The 6-phytase utilized in this study (EC 3.1.3.26 synthesized by Aspergillus oryzae) was a powder commercial product marketed by DSM Company, with determined activity of $9,980 \mathrm{FTU} / \mathrm{g}$ of product, according to the protocol of Engelen et al. (1994). All 5 diets were supplied to male and female broilers for a total of 10 treatments with 3 replications of 4 birds per pen. The use of male and female birds within a cage (mixed housing) could increase the coefficient of variation of the experiment; thus, the sex was considered a factor within the factorial design in order to minimize the variation between repetitions of the same treatment, promoting an experiment with a smaller mean square error.

One hundred and twenty broiler chicks (60 birds of each sex) of the Cobb-500 lineage were acquired at one day of age, sexed, and raised in a conventional shed for broilers up to 14 days of age and received a diet based on corn and soybean meal that was formulated to meet their nutritional requirements (Rostagno et al., 2005). On the 15th day of age, the broilers were weighed individually, separated by weight ranges, and transferred to the cages (experimental unit; with dimensions $50 \times 50 \times 50 \mathrm{~cm}$ ) in a metabolism room. The experimental units were arranged to the average initial weight of the broilers, which was similar to one another $(0.465 \mathrm{~g} \pm 0.002)$. The room offered illumination and thermostatically controlled temperature. Each cage was provided with a pressure-type drinker, an individual guttertype feeder with border, and a tray to collect the excreta. Experimental diets (Table 1) and water were offered $a d$ libitum in the period from 15 to 28 days of age.

The experimental period comprised 13 days, ten days of which were destined for adaptation to the facilities and experimental diets, followed by three days (Rodrigues et al., 2005) of total collection of excreta, per experimental unit. Feed and leftovers were weighed and recorded on the 25th and 28th days of the age of broilers for subsequent calculations of feed intake during that period.

\section{Sample collection and chemical analysis}

The excreta were collected daily in the morning, grouped according to the experimental unit in identified plastic bags, and stored in a freezer up to the last day of collection when the excreta were weighed, homogenized, and pre dried in a forced-ventilation oven at $55^{\circ} \mathrm{C}$ for $72 \mathrm{~h}$. The pre-dried excreta were ground, and the total dry matter content was obtained by considering the loss of moisture during the pre-drying stage and also at $105^{\circ} \mathrm{C}$ until constant weight (method 934.01 of the AOAC, 2005).

The $\mathrm{P}_{\text {phy }}$ content of the excreta was determined by colorimetry according to Frühbeck et al. (1995) with modifications and also by HPLC-IR according to Nappi et al. (2006), with adaptations. Both methodologies were utilized to analyze the extracts obtained in two extraction ratios of mass of sample:volume of extractor solvent (1:20 and 3:20, in $\mathrm{g} / \mathrm{mL}$ ). Parallel to this, three samplings of corn, soybean meal, and the positive and negative control diets were collected, ground, and analyzed in a manner that was similar to the one employed for the excreta. Thus, 1 or $3 \mathrm{~g}$ of sample was suspended in $20 \mathrm{~mL}$ of $0.66 \mathrm{M} \mathrm{HCl}$ followed by mechanical agitation at room temperature during two 
Table 1. Composition and nutritional contents of the experimental diets

\begin{tabular}{|c|c|c|c|}
\hline & \multirow{2}{*}{$\mathrm{PC}^{1}$} & \multirow{2}{*}{$\mathrm{NC}^{2}$} & NC supplemented with phytase \\
\hline & & & $750 / 1,500 / 2,250$ \\
\hline \multicolumn{4}{|l|}{ Ingredient ( $\mathrm{g} / \mathrm{kg}$ of natural matter) } \\
\hline Maize & 596.20 & 604.86 & 604.86 \\
\hline Soybean meal, $48 \% \mathrm{CP}$ & 335.29 & 333.71 & 333.71 \\
\hline Soybean oil & 31.61 & 28.68 & 28.68 \\
\hline Salt & 4.82 & 4.82 & 4.82 \\
\hline L-lysine $\mathrm{HCl} 78 \%$ & 1.67 & 1.70 & 1.70 \\
\hline DL-methionine $99 \%$ & 2.29 & 2.28 & 2.28 \\
\hline L-threonine $98.5 \%$ & 0.35 & 0.35 & 0.35 \\
\hline Mineral premix ${ }^{4}$ & 0.50 & 0.50 & 0.50 \\
\hline Vitamin premix $^{5}$ & 0.40 & 0.40 & 0.40 \\
\hline Choline chloride $60 \%$ & 0.45 & 0.45 & 0.45 \\
\hline Calcitic limestone & 8.74 & 16.10 & 16.10 \\
\hline Dicalcium phosphate & 17.19 & 5.65 & 5.65 \\
\hline Inert (kaolin) & 0.500 & 0.500 & $0.43 / 0.35 / 0.28$ \\
\hline Phytase $^{6}$ & 0.000 & 0.000 & $0.07 / 0.15 / 0.22$ \\
\hline \multicolumn{4}{|c|}{ Calculated nutritional composition ( $\mathrm{g} / \mathrm{kg}$ of natural matter) } \\
\hline Metabolizable energy (kcal/kg) & 3,050 & 3,050 & 3,050 \\
\hline Crude protein & 201.2 & 201.2 & 201.2 \\
\hline Digestible lysine & 11.10 & 11.10 & 11.10 \\
\hline Digestible methionine + cysteine & 7.94 & 7.94 & 7.94 \\
\hline Sodium & 2.10 & 2.10 & 2.10 \\
\hline Calcium & 8.55 & 8.55 & 8.55 \\
\hline Total phosphorus & 6.39 & 4.26 & 4.26 \\
\hline Available phosphorus ${ }^{7}$ & 4.26 & 2.13 & 2.13 \\
\hline Phytate phosphorus $^{8}$ & 2.13 & 2.13 & 2.13 \\
\hline Phytase activity ${ }^{3,6}$ & 0 & 0 & $750 / 1,500 / 2,250$ \\
\hline
\end{tabular}

${ }^{1} \mathrm{PC}$, positive control diet formulated to meet the nutritional requirements of broilers, in the period from 15 to 28 days of age, according to Rostagno et al. (2005).

${ }^{2} \mathrm{NC}$, negative control diet deficient in available phosphorus.

${ }^{3}$ Enzyme supplementation expressed in FTU/kg of diet, in which 1 FTU corresponds to one unit of phytase activity.

${ }^{4}$ Content kg-1 of diet: $55 \mathrm{mg} \mathrm{Zn;} 48 \mathrm{mg} \mathrm{Fe} ; 10 \mathrm{mg} \mathrm{Cu} ; 78 \mathrm{mg} \mathrm{Mn} ; 0.70 \mathrm{mg} \mathrm{I} ; 0.18 \mathrm{mg} \mathrm{Se}$.

${ }^{5}$ Content $\mathrm{kg}^{-1}$ of diet: $4.8 \mathrm{mg}$ vit. $\mathrm{B}_{2} ; 8,000$ UI vit. $\mathrm{A} ; 2,000$ UI vit. $\mathrm{D}_{3} ; 1.2 \mathrm{mg}$ vit. $\mathrm{B}_{1} ; 2.4 \mathrm{mg}$ vit $\mathrm{B}_{6} ; 10.8 \mu \mathrm{g}$ vit. $\mathrm{B}_{12} ; 0.024 \mathrm{mg}$ biotin; $0.64 \mathrm{mg}$ folic acid; $11.6 \mathrm{mg}$ pantothenic acid; $1.92 \mathrm{mg}$ vit. $\mathrm{K}_{3} ; 16.2 \mathrm{UI}$ vit. E.

${ }^{6}$ Ronozyme NP-(CT). 6-phytase (EC 3.1.3.26) synthesized by microorganism Aspergillus oryzae (DSM Company, 17594). Enzyme with declared activity of 10,000 FTU/g of product and determined activity of 9,980 FTU/g of product, according to the protocol of Engelen et al. (1994).

${ }^{7}$ Considering that one-third of the total phosphorus present in the corn and soybean meal correspond to available phosphorus and that the phosphorus supplied by the dicalcium phosphate is $100 \%$ available (Rostagno et al., 2005).

${ }^{8}$ Considering that two-thirds of the total phosphorus present in the corn and soybean meal correspond to phytate phosphorus (Rostagno et al., 2005).

hours. Afterward, the extract was centrifuged at $14,881 \times \mathrm{g}$ for $30 \mathrm{~min}$ at $15^{\circ} \mathrm{C}$, and the supernatant was collected and filtered through Qualy $14 \mu \mathrm{m}$ pore filter paper. At the 1:20 extraction, the filtered supernatant was diluted in function of the concentration of phytate present in the sample and of the standard curve of $\mathrm{IP}_{6}$ (colorimetric method). The dilutions $(\mathrm{v}: \mathrm{v}$ in $\mathrm{mL})$ utilized for the corn, soybean meal, and diets were, respectively, 3:25, 1:25, and 2:25. However, for the excreta, the dilution varied from $1: 25$ to $2: 25$ in function of the treatment because when a higher level of phytase is supplemented in the diet, there is a lower content of $\mathrm{P}_{\text {phy }}$ in the excreta requiring, consequently, a lower dilution level. After the dilution, the $\mathrm{pH}$ was adjusted with
1.0 $\mathrm{M} \mathrm{NaOH}$ to 6.0. In the case of the $3: 20$ extraction, the filtered solution collected after centrifugation had its $\mathrm{pH}$ adjusted to 6.0 without going through the dilution step conducted at the 1:20 extraction.

The sample purification to separate the $\mathrm{P}_{\text {phy }}$ from $\mathrm{P}_{\text {inorg }}$ was conducted in glass columns $(0.7 \times 15 \mathrm{~cm})$ packed with $0.5 \mathrm{~g}$ of anion exchange resin (AG 1-X4, 100-200 dry mesh, Bio-Rad) and washed with $15 \mathrm{~mL}$ of $0.6 \mathrm{M} \mathrm{NaCl}$ and 30 $\mathrm{mL}$ of ultrapure water, respectively. After this resin activation process, $10 \mathrm{~mL}$ of a sample with $\mathrm{pH} 6.0$ were applied to the column, and the eluate was discarded. Subsequently, $15 \mathrm{~mL}$ of $0.6 \mathrm{M} \mathrm{NaCl}$ were utilized for the elution of the polyphosphates retained in the resin, and the 
$\mathrm{pH}$ of the eluate was collected and adjusted to 3.0 with 0.1 $\mathrm{M} \mathrm{HCl}$ because this $\mathrm{pH}$ facilitates the link between phosphate and WR (Latta and Eskin, 1980).

In the sequence of the colorimetric method, an aliquot of the eluate that had been collected $(3 \mathrm{~mL}$ for the 1:20 extraction or 100 to $600 \mu \mathrm{L}$ for the 3:20 extraction; in these latter cases, ultrapure water was pipetted to maintain a final volume of $3 \mathrm{~mL}$ ) was mixed with $1 \mathrm{~mL}$ of WR (consisting of $0.03 \%$ of ferric chloride hexahydrate and $0.3 \%$ of sulfosalicylic acid). The tubes were agitated in a vortex, and absorbance was read at $500 \mathrm{~nm}$ using ultrapure water to zero the spectrophotometer. The standard curve of IP6 was made by pipetting increasing volumes of the stock solution (200 mg/L) of IP 6 (P0109, batch 057k0049, Sigma-Aldrich), so as to obtain concentrations varying from 0 to $150 \mu \mathrm{g}$; each tube received $1 \mathrm{~mL} \mathrm{WR}$, and the final volume was equivalent to $4 \mathrm{~mL}$. The conversion of the concentration of phytate into $\mathrm{P}_{\text {phy }}$ was done considering the molar ratio of the $\mathrm{P}$ in the molecule of $\mathrm{IP}_{6}$ of $28.2 \%$ (Angel et al., 2002).

The remainder of the eluate that had been collected (15 $\mathrm{mL}$ eluted from the anion exchange resin minus the aliquot utilized for the colorimetric determination) was evaporated at $40^{\circ} \mathrm{C}$ till that, a solid residue was obtained, which was subsequently re-suspended in $2 \mathrm{~mL}$ of the mobile phase, centrifuged twice sequentially $\left(15,000 \times \mathrm{g}\right.$ for $10 \mathrm{~min}$ at $\left.4^{\circ} \mathrm{C}\right)$, filtered in a $\mathrm{GV}$ hydrophilic membrane $(0.22 \mu \mathrm{m}$ pore and $25 \mathrm{~mm}$ diameter, Durapore), and stored at $4{ }^{\circ} \mathrm{C}$ until quantification of the myo-inositol phosphates by HPLC-IR.

The mobile phase consisted of $900 \mathrm{~mL}$ of $50 \mathrm{mM}$ formic acid, $900 \mathrm{~mL}$ of methanol, $45 \mathrm{~mL}$ of $5 \mathrm{mM}$ EDTA, and $54 \mathrm{~mL}$ of tetrabutylammonium hydroxide $20 \%$. The $\mathrm{pH}$ of the mobile phase was adjusted to 4.3 with sulfuric acid and before being injected in the chromatograph, the mobile phase was vacuum filtered and sonicated (degassed) for 50 min. The analyses were performed in a Shimadzu chromatograph that was equipped with a refractive index detector (RID10A $i$ ) and a $\mathrm{C}_{18}$ CAPCELL PAK column (5 $\mu \mathrm{m} \times 4.6 \mathrm{~mm} \times 150 \mathrm{~mm}$ ) with a mobile phase at a flow of 0.5 $\mathrm{mL} / \mathrm{min}$. The temperature of the oven was maintained at $45^{\circ} \mathrm{C}$, and the injection volume was $20 \mu \mathrm{L}$.

For the identification of phosphorylated fractions, the retention time of the standard compounds myo-inositol hexaphosphate or phytic acid $\left(\mathrm{IP}_{6}\right.$, code $\mathrm{P} 0109$, batch 057k0049); myo-inositol-1,3,4,5,6-pentaphosphate $\left(\mathrm{IP}_{5}\right.$, code I9261, batch 114K12831); myo-inositol-1,3,4,6tetraphosphate $\left(\mathrm{IP}_{4}\right.$, code $\mathrm{I9386}$, batch 60K17321); and myo-inositol-1,4,5-triphosphate $\left(\mathrm{IP}_{3}\right.$, code. I8761, batch 21H84341), obtained under the same conditions of analysis, were compared with the retention times of the peaks obtained in the samples. The $\mathrm{IP}_{5}$ was utilized as an internal standard for quantification of the phosphorylated fractions $\left(\mathrm{IP}_{3}\right.$ to $\left.\mathrm{IP}_{6}\right)$ present in the samples using the following equation (Sandberg and Ahderinne, 1986):

Concentration of $\mathrm{IP}_{\mathrm{Y}}$ in the sample (in $\mathrm{mg} / \mathrm{mL}$ )

$=\frac{0.32 \times \mathrm{IP}_{\mathrm{Y}} \text { peak area in the sample }}{\text { Peak area of the internal standard }}$

In this equation, $\mathrm{IP}_{\mathrm{Y}}$ corresponds to the different fractions of myo-inositol phosphates $\left(\mathrm{IP}_{3}, \mathrm{IP}_{4}, \mathrm{IP}_{5}\right.$, or $\left.\mathrm{IP}_{6}\right)$. The conversion of the concentration of $\mathrm{IP}_{6}$ in $\mathrm{P}$ was calculated, considering the molar ratio of $\mathrm{P}$ in the $\mathrm{IP}_{6}$ molecule, which is $28.2 \%$. For fractions $\mathrm{IP}_{5}, \mathrm{IP}_{4}$, and $\mathrm{IP}_{3}$, the molar ratios of $26.7,24.8$, and $22.1 \%$, respectively, were utilized.

The protein content in the extracts ( $\mathrm{mg}$ of protein per $\mathrm{ml}$ of extract) was dosed according to method of Bradford (1976) by utilizing bovine serum albumin as a standard. This analysis was conducted in samples extracts centrifuged and no centrifuged to investigate the hypothesis of that phytate can form complexes with proteins of manner that these phytate-protein complexes can interfere in the phytate quantification.

\section{Balance and coefficient of hydrolysis (or retention) of phytate phosphorus}

These parameters were calculated on a dry matter basis, utilizing the $\mathrm{P}_{\text {phy }}$ contents determined by the two methodologies evaluated. The $\mathrm{P}_{\text {phy }}$ intake (g/bird) was calculated by multiplying the feed intake (g/bird) by the $\mathrm{P}_{\text {phy }}$ content $(\%)$ in the feed. To calculate the absolute excretion of $\mathrm{P}_{\text {phy }}(\mathrm{g} / \mathrm{bird})$, the amount of excreta ( $\left.\mathrm{g} / \mathrm{bird}\right)$ was multiplied by the $\mathrm{P}_{\text {phy }}$ content $(\%)$ in the excreta. The hydrolysis coefficient of $\mathrm{P}_{\text {phy }}$ was calculated by equation:

$$
\begin{aligned}
& \text { Coefficient of hy droly sisof } \mathrm{P}_{\text {phy }} \\
& =\frac{\left(\mathrm{P}_{\text {phy }} \text { intake }- \text { excretion of } \mathrm{P}_{\mathrm{phy}}\right) \times 100}{\mathrm{P}_{\mathrm{phy}} \text { intake }}
\end{aligned}
$$

\section{Statistical analysis}

Each cage was considered one experimental unit, and an independent statistical analysis was conducted for each analytical methodology evaluated. The data of the intake, excretion, and coefficient of hydrolysis of $\mathrm{P}_{\text {phy }}$ were subjected to analysis of variance $(\mathrm{p}<.05)$ by utilizing command General Linear Model of software SAS (2004), and when significant, polynomial regression models were utilized $(p<0.05)$ to evaluate the effect of increasing supplementation of phytase on these parameters. The significance of the effect of the sex of birds was evaluated by the $F$ test itself $(p<0.05)$. In addition, the positive control diet was compared with the other experimental diets by the Dunnett test $(\mathrm{p}<0.05)$. 


\section{RESULTS AND DISCUSSION}

\section{Concentrations of phytate and phytate phosphorus determined in ingredients, diets and excreta}

The initial proposal of this research was to compare the two analytical methodologies (colorimetry and HPLC-IR) only at the extraction ratio of 1:20 (mass of sample in $\mathrm{g}$ :volume of extractor solvent in $\mathrm{mL}$ ), as Brito (2008) had already managed to quantify phytate in diets and excreta from broilers by colorimetry at this extraction ratio. However, with the 1:20 extraction, it was not possible to detect all the peaks with regard to the phosphorylated fractions of myo-inositol by the HPLC-IR method (especially for the samples of excreta from broilers fed the diets containing the highest levels of phytase) and, besides, the peaks identified in the chromatogram presented an intensity that was inferior to the limit of quantification of the analyte in the analysis conditions. Therefore, the extract was concentrated so as to enable the analytes of interest to be quantified via HPLC. During this procedure of concentration of the extract, it was observed that the highest possible ratio was of 3:20 because at higher ratios, the sample would become pasty, which is undesirable, as this could compromise the process of solubilization of the analytes.

For the colorimetric method, the extraction at the ratio of 3:20 resulted in the determination of lower concentrations of phytate and, consequently, lower contents of $\mathrm{P}_{\text {phy }}$ (Tables 2 and 3), probably due to the interference from the proteins present in this extract. According to Frühbeck et al. (1995), the $\mathrm{pH}$ of the diluted aliquot should be adjusted to 6.0 because this value is above of the isoelectric point of most of the vegetable proteins; which means that in theory, these proteins would present negative net charge and there would be electrostatic repulsion with the phytate, thus preventing the formation of complexes between inositol phosphate (IP) and protein. However, it appears that the formation of these phytate-protein complexes occurred, even adjusting the $\mathrm{pH}$ to 6.0.

To investigate the formation of these phytate-protein complexes, samples extracted at the ratio of 3:20 were centrifuged, and a great amount of precipitate (pellet) was visually verified, with only $52.07 \pm 2.32 \mu \mathrm{g}$ protein per $\mathrm{ml}$ of extract determined in the supernatant (the non-centrifuged extracts resulting from extraction ratios of 1:20 and 3:20 had presented $109.41 \pm 1.30$ and $800.73 \pm 1.71 \mu \mathrm{g}$ protein $/ \mathrm{mL}$, respectively). Moreover, no trace of phytate was detected in the centrifuged supernatant, reinforcing the hypothesis that phytate was complexed with the proteins from the sample, and precipitated after centrifugation due to the high molecular weight of these phytate-protein complexes.

Furthermore, with the 1:20 extraction, the sample would naturally go through the anion exchange resin by the action of gravity; however, with the 3:20 extraction, the sample appeared blurred, and for their passage through the resin, a pressure pump had to be used. Therefore, at the extraction ratio of 3:20, the complexation with proteins results in an underestimation of the phytate content because an portion of the IP-protein complexes probably does not go through resin, and those which might be eluted with the saline solution, cannot be properly quantified due to their inadequate reaction with the WR. In addition to the proteins, phytate can also complex with minerals (Kornegay, 2001), which might interfere in the dosage of phytate; however, as the protein content in the diet is much higher than the mineral content, it is likely that the effect of protein is more pronounced.

When the extract at the rate of 1:20 was dosed by the colorimetric method (Table 2), the contents of $\mathrm{P}_{\text {phy }}$ determined for corn and soybean meal in this study were approximately $30 \%$ and $44 \%$ higher than the mean values presented in the last edition of the Brazilian Tables for Poultry and Swine: 0.217 and $0.437 \mathrm{~g} \mathrm{P}_{\text {phy }}$ per $100 \mathrm{~g} \mathrm{DM}$ of corn and soybean meal, respectively (Rostagno et al., 2011); however, the methodology utilized for the determination of these contents was not published. In addition to the methodology, the differences observed can also be due to environmental, genetic, and/or cultivation variations, which can alter the content of $\mathrm{P}_{\text {phy }}$ in the seeds and grains. For example, Wadt et al. (2010) collected 94 samples of corn originated from the South, Southeast, and Midwest regions of the Brazil in the summer 2009 harvest, and they verified differences not only within the same region but also between cultivation regions, with $\mathrm{P}_{\text {phy }}$ contents determined raging from 1.0 to $2.6 \mathrm{~g} / \mathrm{kg}$ of corn, which represents a variation of up to $160 \%$ in the $\mathrm{P}_{\text {phy }}$ contents determined in the samples. Therefore, in this study, the colorimetric methodology at the extraction ratio of 1:20 was shown to be the most adequate method for quantifying the $\mathrm{P}_{\text {phy }}$.

The retention times (in minutes) for standards $\mathrm{IP}_{3}, \mathrm{IP}_{4}$, $\mathrm{IP}_{5}$, and $\mathrm{IP}_{6}$ were $6.793,10.386,15.113$, and 18.791, respectively. The $\mathrm{P}_{\text {phy }}$ contents determined in corn, soybean meal, and diets by the HPLC-IR methodology at the extraction ratio of 3:20 were inferior to those determined by the colorimetric method at the extraction ratio of 1:20 (Table 2), which also should be due to the complexation of phytate with other molecules present in the sample, especially proteins. However, this was not observed for the excreta, which can be justified by the profile of esters of myo-inositol phosphate present in the sample (Table 3).

In general, the higher the degree of phosphorylation of myo-inositol, the higher its power of complexation because the greater the number of phosphate groups in the molecule, the greater the number of negative charges resulting from 
Table 2. Contents of phytate and phytate phosphorus in ingredients and diets, determined according to two analytical methodologies and extraction ratios

\begin{tabular}{|c|c|c|c|c|}
\hline$\overline{\text { Content }(\mathrm{g} / 100 \mathrm{~g} \text { of dry matter) }}$ & Corn & Soybean meal & $\mathrm{NC} \operatorname{diet}^{1}$ & $\mathrm{PC}$ diet $^{2}$ \\
\hline \multicolumn{5}{|l|}{$\overline{\text { HPLC-IR }}{ }^{3,4} 3: 20$ (m:v) } \\
\hline Total myo-inositol phosphates ${ }^{5}$ & 0.031 & 0.549 & 0.173 & 0.179 \\
\hline Phytate phosphorus ${ }^{6}$ & 0.009 & 0.154 & 0.049 & 0.050 \\
\hline $\mathrm{P}$ of $\mathrm{IP}_{3}$ & 0.000 & 0.000 & 0.000 & 0.000 \\
\hline $\mathrm{P}$ of $\mathrm{IP}_{4}$ & 0.000 & 0.000 & 0.000 & 0.000 \\
\hline $\mathrm{P}$ of $\mathrm{IP}_{5}$ & 0.000 & 0.018 & 0.008 & 0.008 \\
\hline $\mathrm{P}$ of $\mathrm{IP}_{6}$ & 0.009 & 0.136 & 0.041 & 0.042 \\
\hline \multicolumn{5}{|l|}{ Colorimetry 3:20 (m:v) } \\
\hline Phytate & 0.107 & 0.375 & 0.112 & 0.106 \\
\hline Phytate phosphorus ${ }^{7}$ & 0.030 & 0.106 & 0.032 & 0.030 \\
\hline \multicolumn{5}{|l|}{ Colorimetry 1:20 (m:v) } \\
\hline Phytate & 1.000 & 2.230 & 1.341 & 1.348 \\
\hline Phytate phosphorus ${ }^{7}$ & 0.282 & 0.629 & 0.378 & 0.380 \\
\hline
\end{tabular}

m:v, mass of sample in $\mathrm{g}$ :volume of extractor solvent in $\mathrm{mL}$.

$\mathrm{IP}_{\mathrm{x}}$, myo-inositol phosphates, wherein $\times$ corresponds to the degree of phosphorylation of the molecule.

${ }^{1}$ Negative control (NC) diet formulated with $2.13 \mathrm{~g}$ of available phosphorus $/ \mathrm{kg}$ of diet.

${ }^{2}$ Positive control (PC) diet formulated with $4.26 \mathrm{~g}$ of available phosphorus $/ \mathrm{kg}$ of diet.

${ }^{3}$ HPLC-IR, high-performance liquid chromatography with refractive index detector.

${ }^{4}$ At the extraction ratio of 1:20 (m:v), the concentration of myo-inositol phosphates in the aliquot injected in the chromatograph was below of the limit of detection and/or quantification.

${ }^{5}$ Corresponding to the sum of fractions $\mathrm{IP}_{3}, \mathrm{IP}_{4}, \mathrm{IP}_{5}$, and $\mathrm{IP}_{6}$.

${ }^{6}$ Phytate phosphorus $(\%)=\left(\%\right.$ of $\left.\mathrm{IP}_{3} \times 0.221\right)+\left(\%\right.$ of $\left.\mathrm{IP}_{4} \times 0.248\right)+\left(\%\right.$ of $\left.\mathrm{IP}_{5} \times 0.267\right)+\left(\%\right.$ of $\left.\mathrm{IP}_{6} \times 0.282\right)$.

${ }^{7}$ Phytate phosphorus $(\%)=$ determined phytate content $(\%) \times 0.282$.

the deprotonation of these phosphate groups (Kornegay, 2001). In this sense, Yu et al. (2012) recently evaluated the effect of the degree of phosphorylation of myo-inositol on the potential of the molecule to complex with the soy protein and bovine $\beta$-casein and concluded that, for both proteins, $\mathrm{IP}_{6}$ has a high chelating power which is strongly reduced by the loss of one phosphate group $\left(\mathrm{IP}_{5}\right)$, becoming practically null in the other phosphorylated fractions $\left(\mathrm{IP}_{4}\right.$ to $\left.\mathrm{IP}_{1}\right)$. Therefore, due to the fractions with fewer than five phosphate groups in the excreta (Table 3), the interference of the proteins in these samples was lower than in the ingredients and diets.

In the corn, only fraction $\mathrm{IP}_{6}$ was detected; whereas in soybean meal and the diets, the myo-inositol phosphates were distributed between $\mathrm{IP}_{5}$ and $\mathrm{IP}_{6}$, but with predominance of $\mathrm{IP}_{6}$ (Table 2). Consequently, probably there were high rates of complexing of these fractions with other molecules or ions, and once complexed, the physicochemical properties of these complexes are different from isolated fractions, thus causing alterations in the retention times, impeding these complexes from being identified in the chromatogram, leading to underestimation of the results. This interference by the formation of complexes was lower in the excreta due to the predominance of fractions with low complexing capacity such as $\mathrm{IP}_{4}$ and $\mathrm{IP}_{3}$, which are products from the enzymatic action of phytase on the phytate.

\section{Balance and coefficient of hydrolysis (or retention) of phytate phosphorus}

Although it is possible to make comparisons between the methodologies to quantify $\mathrm{P}_{\text {phy }}$ based on the contents determined, these data are inappropriate to evaluate the phytase efficiency to make $\mathrm{P}_{\text {phy }}$ available for broilers. Therefore, it is necessary to take into account not only the $\mathrm{P}_{\text {phy }}$ content determined in the diets and excreta, but also the feed intake and the amount of excreta produced in the collection period. As previously discussed, the methodologies of colorimetry and HPLC-IR at the extraction ratio of $3: 20$ presented problems in the determination of the $\mathrm{P}_{\text {phy }}$ content, which is reflected in inadequate balance and retention of $\mathrm{P}_{\text {phy }}$ (Table 4).

In this regard, the colorimetric methodology with the extraction ratio of 1:20 was shown to be the most adequate, and, therefore, presented the most reliable results on the balance and retention of $\mathrm{P}_{\text {phy }}$ by the broilers (Table 4). There was no interaction $(p>0.05)$ between the levels of phytase and sex for intake, excretion, or the coefficient of hydrolysis of $\mathrm{P}_{\text {phy }}$. In addition, the birds sex affected $(p<0.01)$ only the intake of $P_{\text {phy }}$, so that the males consumed $12 \%$ more $\mathrm{P}_{\mathrm{phy}}$ than did the females. Therefore, it is possible to consider that the mean values obtained to calculate the regression equations for the excretion and the retention coefficient were originated from six replicates (three for each sex). The increase in the phytase level in the diet did not affect $(p>0.05)$ intake, but linearly reduced 
Table 3. Contents of phytate and phytate phosphorus $\left(\mathrm{P}_{\mathrm{phy}}\right)$ in excreta from male and female broilers, determined according to two analytical methodologies and extraction ratios

\begin{tabular}{|c|c|c|c|c|c|}
\hline \multirow{2}{*}{$\begin{array}{l}\text { Content } \\
\text { (g/100 g of dry matter) }\end{array}$} & \multicolumn{4}{|c|}{ Calculated nutritional composition (g/kg of natural matter) } & \multirow{2}{*}{ PC diet ${ }^{2}$} \\
\hline & 0 & 750 & 1,500 & 2,250 & \\
\hline \multicolumn{6}{|l|}{ HPLC-IR ${ }^{3,4} 3: 20(\mathrm{~m}: \mathrm{v})$} \\
\hline \multicolumn{6}{|c|}{ Total myo-inositol phosphates ${ }^{5}$} \\
\hline Male & 3.840 & 3.994 & 2.750 & 2.719 & 3.784 \\
\hline Female & 4.527 & 2.866 & 2.212 & 2.505 & 4.480 \\
\hline \multicolumn{6}{|l|}{ Phytate phosphorus $^{6}$} \\
\hline Male & 0.856 & 0.888 & 0.614 & 0.608 & 0.844 \\
\hline Female & 1.010 & 0.640 & 0.494 & 0.560 & 1.000 \\
\hline \multicolumn{6}{|l|}{$\mathrm{P}$ of $\mathrm{IP}_{3}$} \\
\hline Male & 0.799 & 0.849 & 0.567 & 0.559 & 0.782 \\
\hline Female & 0.938 & 0.590 & 0.458 & 0.512 & 0.921 \\
\hline \multicolumn{6}{|l|}{$\mathrm{P}$ of $\mathrm{IP}_{4}$} \\
\hline Male & 0.036 & 0.024 & 0.029 & 0.030 & 0.043 \\
\hline Female & 0.054 & 0.033 & 0.024 & 0.030 & 0.059 \\
\hline \multicolumn{6}{|l|}{$\mathrm{P}$ of $\mathrm{IP}_{5}$} \\
\hline Male & 0.014 & 0.013 & 0.014 & 0.016 & 0.015 \\
\hline Female & 0.016 & 0.013 & 0.011 & 0.015 & 0.018 \\
\hline \multicolumn{6}{|l|}{$\mathrm{P}$ of $\mathrm{IP}_{6}$} \\
\hline Male & 0.007 & 0.002 & 0.004 & 0.003 & 0.004 \\
\hline Female & 0.002 & 0.004 & 0.001 & 0.003 & 0.002 \\
\hline \multicolumn{6}{|l|}{ Colorimetry 3:20 (m:v) } \\
\hline \multicolumn{6}{|l|}{ Phytate } \\
\hline Male & 0.244 & 0.168 & 0.066 & 0.090 & 0.316 \\
\hline Female & 0.118 & 0.076 & 0.070 & 0.083 & 0.344 \\
\hline \multicolumn{6}{|l|}{ Phytate phosphorus ${ }^{7}$} \\
\hline Male & 0.069 & 0.047 & 0.019 & 0.025 & 0.089 \\
\hline Female & 0.033 & 0.021 & 0.020 & 0.023 & 0.097 \\
\hline \multicolumn{6}{|l|}{ Colorimetry 1:20 (m:v) } \\
\hline \multicolumn{6}{|l|}{ Phytate } \\
\hline Male & 1.519 & 1.456 & 0.458 & 0.655 & 2.425 \\
\hline Female & 1.566 & 0.757 & 0.809 & 0.753 & 3.004 \\
\hline \multicolumn{6}{|l|}{ Phytate phosphorus ${ }^{7}$} \\
\hline Male & 0.428 & 0.411 & 0.129 & 0.185 & 0.684 \\
\hline Female & 0.442 & 0.213 & 0.228 & 0.212 & 0.847 \\
\hline
\end{tabular}

m:v, mass of sample in $\mathrm{g}:$ volume of extractor solvent in $\mathrm{mL}$.

$\mathrm{IP}_{\mathrm{x}}$, myo-inositol phosphates, wherein $\times$ corresponds to the degree of phosphorylation of the molecule.

${ }^{1}$ Negative control (NC) diet, without phytase, formulated with $2.13 \mathrm{~g}$ of available phosphorus $/ \mathrm{kg}$ of diet.

${ }^{2}$ Positive control (PC) diet, without phytase, formulated with $4.26 \mathrm{~g}$ of available phosphorus/kg of diet.

${ }^{3}$ HPLC-IR, high-performance liquid chromatography with refractive index detector.

${ }^{4}$ At the extraction ratio of 1:20 (m:v), the concentration of myo-inositol phosphates in the aliquot injected in the chromatograph was below of the limit of detection and/or quantification.

${ }^{5}$ Corresponding to the sum of fractions $\mathrm{IP}_{3}, \mathrm{IP}_{4}, \mathrm{IP}_{5}$, and $\mathrm{IP}_{6}$.

${ }^{6}$ Phytate phosphorus $(\%)=\left(\%\right.$ of $\left.\mathrm{IP}_{3} \times 0.221\right)+\left(\%\right.$ of $\left.\mathrm{IP}_{4} \times 0.248\right)+\left(\%\right.$ of $\left.\mathrm{IP}_{5} \times 0.267\right)+\left(\%\right.$ of $\left.\mathrm{IP}_{6} \times 0.282\right)$.

${ }^{7}$ Phytate phosphorus $(\%)=$ determined phytate content $(\%) \times 0.282$.

( $\mathrm{p}<0.01)$ the $\mathrm{P}_{\text {phy }}$ excretion up to $57.75 \%$, which represents good results, as it demonstrates the possibility of producing broilers with less $\mathrm{P}$ deposition in the environment using phytase in the diet.

In the diets without supplemented phytase, there was good use of the $\mathrm{P}_{\text {phy }}$ present in the diet, which was similar to the observations by Han et al. (2009), who attributed this result to the action of the endogenous phytase that can be synthesized by cells of the intestinal epithelium of broilers (Applegate et al., 2003). Besides, the decrease of $\mathrm{P}_{\mathrm{av}}$ from 4.26 to $2.13 \mathrm{~g} / \mathrm{kg}$ of the diet increased the coefficient of hydrolysis of the $\mathrm{P}_{\text {phy }}$ from $43.37 \%$ to $69.67 \%$, which was similar to the results reported by Onyango et al. (2006), who evaluated the effect of two levels of $\mathrm{P}$ in the diet 
Table 4. Balance (g/bird) and retention (\%) of phytate phosphorus (in dry matter) of male and female broilers fed diets deficient in available phosphorus supplemented with increasing levels of phytase, utilizing two analytical methodologies and extraction ratios for the determination of the content of phytate phosphorus in the diets and excreta

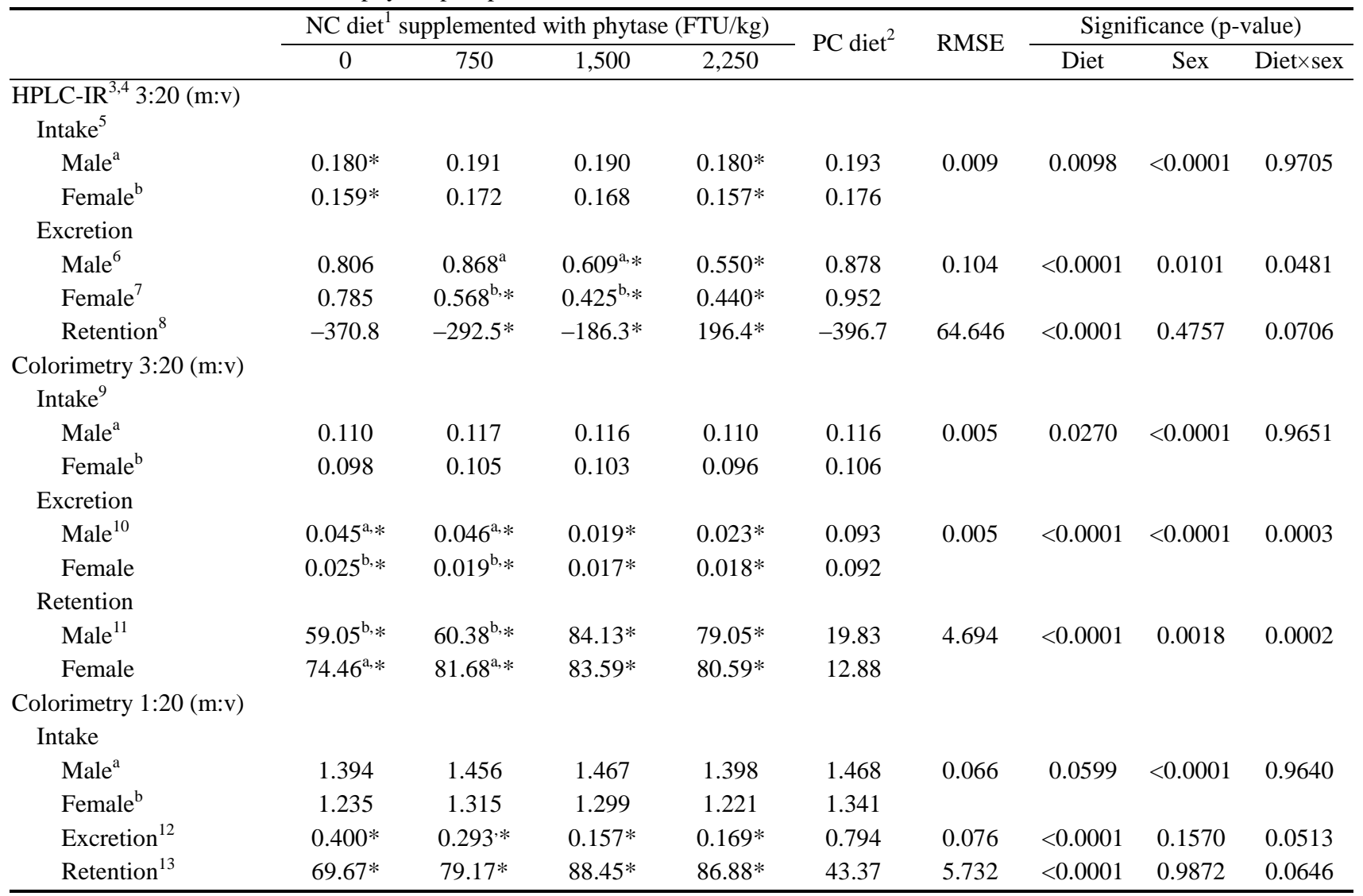

$\mathrm{m}: \mathrm{v}$, mass of sample in $\mathrm{g}:$ volume of extractor solvent in ml. FTU, units of phytase activity. RMSE, root mean square error.

${ }^{1}$ Negative control (NC) diet, without phytase, formulated with $2.13 \mathrm{~g}$ of available phosphorus $/ \mathrm{kg}$ of diet.

${ }^{2}$ Positive control (PC) diet, without phytase, formulated with $4.26 \mathrm{~g}$ of available phosphorus $/ \mathrm{kg}$ of diet.

${ }^{3}$ HPLC-IR, high-performance liquid chromatography with refractive index detector.

${ }^{4}$ At the extraction ratio of 1:20 (m:v), the concentration of myo-inositol phosphates in the aliquot injected in the chromatograph was below of the limit of detection and/or quantification.

${ }^{5}$ Phytate phosphorus intake $=\left(-1.00701 \times 10^{-8}\right) \mathrm{x}^{2}+0.0000218 \mathrm{x}+0.170\left(\mathrm{R}^{2}=0.99\right)$.

${ }^{6}$ Phytate phosphorus excretion by male broilers $=-0.000137 x+0.863\left(R^{2}=0.75\right)$.

${ }^{7}$ Phytate phosphorus excretion by female broilers $=-0.000157 \mathrm{x}+0.731\left(\mathrm{R}^{2}=0.83\right)$.

${ }^{8}$ Phytate phosphorus retention $=0.0840 \mathrm{x}-355.889\left(\mathrm{R}^{2}=0.87\right)$.

${ }^{9}$ Phytate phosphorus intake $=\left(6.17 \times 10^{-9}\right) \mathrm{x}^{2}+\left(1.33 \times 10^{-5}\right) \mathrm{x}+0.104\left(\mathrm{R}^{2}=0.99\right)$.

${ }^{10}$ Phytate phosphorus excretion by male broilers $=-0.0000125 x+0.047\left(R^{2}=0.68\right)$.

${ }^{11}$ Phytate phosphorus retention by male broilers $=0.0112 \mathrm{x}+58.089\left(\mathrm{R}^{2}=0.71\right)$.

${ }^{12}$ Phytate phosphorus excretion $=-0.000110 x+0.379\left(\mathrm{R}^{2}=0.87\right)$.

${ }^{13}$ Phytate phosphorus retention $=-0.00000492 x^{2}+0.0120 x+69.14\left(R^{2}=0.97\right)$.

* Differs from the positive control diet by the Dunnett test $(\mathrm{p}<0.05)$.

${ }^{\mathrm{a}, \mathrm{b}}$ Means in a column with different superscripts letters differ by the $\mathrm{F}$ test $(\mathrm{p}<0.05)$.

(without phytase supplementation) on the activity of phytase present in the intestinal mucosa (duodenum) of broilers, in the period from 8 to 20 days of age, and observed that the activity of this enzyme rose from 29.46 to 43.25 nmols of ${ }_{\text {inorg }} \mathrm{P} / \mathrm{mg}$ of protein per min when the concentration of total $\mathrm{P}$ in the diet was reduced from 7.0 to $3.6 \mathrm{~g} / \mathrm{kg}$ of diet. These results suggest that there is an influence of dietary P levels on the activity and efficacy of intestinal phytase, although the mechanisms are not yet fully understood (Bedford and Partridge, 2010). One possible biochemical explication for these results is based in the mechanism of enzymatic inhibition in the presence of the product from catalysis of manner that the increase in the $\mathrm{P}_{\text {inorg }}$ concentration in the diet causes a down-regulation in the activity of the intestinal phytase (Onyango et al., 2006).

The increase in the inclusion of phytase in the diet increased $(\mathrm{p}<0.01)$ the retention of $\mathrm{P}_{\text {phy }}$, corroborating with the research of Han et al. (2009), who also verified increasing improvement in the $\mathrm{P}_{\text {phy }}$ retention in function of increase in the phytase level in the diet. The greatest 
retention coefficient was estimated at $87.85 \%$ when the diet contained 1,950 FTU/kg of diet (Coefficient of retention of the $\left.\mathrm{P}_{\text {phy }}=-0.00000492 \mathrm{x}^{2}+0.01919 \mathrm{x}+69.14 ; \mathrm{R}^{2}=0.97\right)$. Thus, as the mean content of $\mathrm{P}_{\text {phy }}$ determined in the diet was $3.25 \mathrm{~g} \mathrm{P}_{\text {phy }} / \mathrm{kg}$ of the diet in natural matter (considering the mean determined value of $3.78 \mathrm{~g} \mathrm{P} \mathrm{P}_{\text {phy }} / \mathrm{kg}$ of diet in DM and the content of moisture of $13.88 \% \pm 0.45$ ), it is possible to reduce the $\mathrm{P}$ content in the diet in $87.85 \%$ (or $2.86 \mathrm{~g}$ of $\mathrm{P}$ per $\mathrm{kg}$ ) by adding $1,950 \mathrm{FTU} / \mathrm{kg}$ of the diet.

\section{IMPLICATIONS}

The extraction ratio and methodology of dosage utilized to determine the $\mathrm{P}_{\text {phy }}$ content in both the diets and excreta from broilers interfere directly with the results of $\mathrm{P}_{\text {phy }}$ retention. The combination of the extraction ratio of 1:20 (mass of sample in g:volume of extractor solvent in $\mathrm{mL}$ ) and colorimetric methodology is the one that yielded the best results. The broiler sex did not affect the $\mathrm{P}_{\text {phy }}$ utilization, in the period from 15 to 28 days of age. Supplementation of $1,950 \mathrm{FTU} / \mathrm{kg}$ corresponds to a reduction of $2.86 \mathrm{~g}$ in $\mathrm{P} / \mathrm{kg}$ of the diet.

\section{ACKNOWLEDGMENTS}

The work was supported by the CNPq (National Council for Scientific and Technological Development) and by the FAPEMIG (Foundation to Support Research of the State of Minas Gerais), Brazil.

\section{REFERENCES}

Angel, R., N. M. Tamim, T. J. Applegate, A. S. Dhandu, and L. E. Ellestad. 2002. Phytic acid chemistry: Influence on phytinphosphorus availability and phytase efficacy. J. Appl. Poult. Res. 11:471-480.

AOAC. 2005. Official Methods of Analysis. 18th edn. Association of Official Analytical Chemists, Gaithersburg, USA.

Applegate, T. J., R. Angel, and H. L. Classen. 2003. Effect of dietary calcium, 25-hydroxycholecalciferol, or bird strain on small intestinal phytase activity in broiler chickens. Poult. Sci. 82:1140-1148.

Bedford, M. R. and G. G. Partridge. 2010. Enzymes and Farm Animal Nutrition. 2nd edn. CABI, Cambridge, England.

Bradford, M. M. 1976. A rapid and sensitive method for the quantitation of microgram quantities of protein utilizing the principle of protein-dye binding. Anal. Biochem. 72:248-254.

Brito, J. A. 2008. Vitamin $\mathrm{D}_{3}$ (cholecalciferol) and 25-hydroxycholecalciferol $\left(25-\mathrm{OHD}_{3}\right)$ in Broiler Diets. Ph.D. Thesis. Federal University of Lavras, Lavras, Minas Gerais, Brazil.

Cúneo, F., J. Amaya-Farfan, and F. Carraro. 2000. Phytate distribution in stabilized rice bran treated with exogenous phytase. Ciênc. Tecnol. Aliment. 20:94-98.

Engelen, A. J., F. C. Van der Heeft, P. H. G. Randsdorp, and E. L. C. Smit. 1994. Simple and rapid determination of phytase activity. J. AOAC Int. 77:760-764.

Frühbeck, G., R. Alonso, F. Marzo, and S Santidrián. 1995. A modified method for the indirect quantitative analysis of phytate in foodstuffs. Anal. Biochem. 225:206-212.

Gomide, E. M., P. B. Rodrigues, L. de P. Naves, V. M. P. Bernardino, L. M. dos Santos, and A. A. P Garcia. 2012. Diets with reduced levels of nutrients supplemented with phytase and amino acids for broilers. Ciênc. agrotec. 36:100-107.

Greiner, R., A. Farouk, M. L. Alminger, and N. G. Carlsson. 2002. The pathway of dephosphorylation of myo-inositol hexakisphosphate by phytate-degrading enzymes of different Bacillus spp. Can. J. Microbiol. 48:986-994.

Han, J. C., X. D. Yang, H. X. Qu, M. Xu, T. Zhang, W. L. Li, J. H. Yao, Y. R. Liu, B. J. Shi, J. F. Zhou, and X. Y. Feng. 2009. Evaluation of equivalency values of microbial phytase to inorganic phosphorus in 22- to 42-day-old broilers. J. Appl. Poult. Res. 18:707-715.

Kornegay, E. T. 2001. Digestion of phosphorus and other nutrients: the role of phytases and factors influencing their activity. In: Enzymes in Farm Animal Nutrition (Ed. M. R. Bedford and G. G. Partridge). Finnfeeds International, Marlborough, Wiltshire, UK. p. 237-271.

Latta, M. and M. Eskin. 1980. A simple and rapid colorimetric method for phytate determination. J. Agric. Food Chem. 28:1313-1315.

Nagata, A. K., P. B. Rodrigues, R. R. Alvarenga, M. G. Zangerônimo, K. F. Rodrigues, and G. F. R. Lima. 2011. Energy and protein levels in diets containing phytase for broilers from 22 to 42 days of age: performance and nutrient excretion. R. Bras. Zootec. 40:1718-1724.

Nappi, G. U., M. R. Ribeiro-Cunha, J. V. Coelho, and L. Jokl. 2006. Validation methods to determine phytic and oxalic acids in "multimisturas". Ciênc. Tecnol. Aliment. 26:811-820.

Onyango, E. M., E. K. Asem, and O. Adeola. 2006. Dietary cholecalciferol and phosphorus influence intestinal mucosa phytase activity in broilers chicks. Br. Poult. Sci. 47:632-639.

Rodrigues, P. B., R. S. Martinez, R. T. F. Freitas, A. G. Bertechini, and E. T. Fialho. 2005. Effect of collection time and methodologies on the digestibility and energy value of poultry diets. R. Bras. Zootec. 34:882-889.

Rostagno, H. S., L. F. T. Albino, J. L. Donzele, P. C. Gomes, R. F. de Oliveira, D. C. Lopes, A. S. Ferreira, and S. L. T. Barreto. 2005. Brazilian Table for Poultry and Pigs: Food Composition and Nutritional Requirements. 2ed. Federal University of Viçosa, Minas Gerais, Brazil.

Rostagno, H. S., L. F. T. Albino, J. L. Donzele, P. C. Gomes, R. F. de Oliveira, D. C. Lopes, A. S. Ferreira, S. L. T. Barreto, and R. F. Euclides. 2011. Brazilian Table for Poultry and Pigs: Food Composition and Nutritional Requirements. 3ed. Federal University of Viçosa, Minas Gerais, Brazil.

Sandberg, A. S. and R. Ahderinne. 1986. HPLC method for determination of inositol tri-, tetra-, penta and hexaphosphates in foods and intestinal contents. J. Food Sci. 51:547-550.

Santos, L. M. dos, P. B. Rodrigues, R. R. Alvarenga, L. de P. Naves, R. Hespanhol, G. F. R. Lima, M. C. C. Lara, and L. R. Silva. 2011a. Calcium and available phosphorus levels in diets supplemented with phytase for broilers in the growing and finishing phases. R. Bras. Zootec. 40:2486-2495. 
Santos, L. M. dos, P. B. Rodrigues, R. T. F. Freitas, A. G.
Bertechini, E. T. Fialho, E. M. Gomide, and L. de P. Naves. 2011b. Calcium and available phosphorus levels in diets with phytase for broilers in the pre-starter and starter phases. R. Bras. Zootec. 40:2476-2485.

SAS Institute Inc. 2004. Statistical Analysis System User's Guide: Version 9.1. SAS Institute Inc., Cary, NC, USA.
Yu, S., A. Cowieson, C. Gilbert, P. Plumstead, and S. Dalsgaard. 2012. Interactions of phytate and myo-inositol phosphate esters $\left(\mathrm{IP}_{1-5}\right)$ including $\mathrm{IP}_{5}$ isomers with dietary protein and iron and inhibition of pepsin. J. Anim. Sci. 90:1824-1832.

Wadt, G., T. T. Santos, G. A. Gomes, A. Cowieson, and M. R. Bedford. 2010. Total and phytate phosphorus in corn samples collected from different regions of the Brazil. In: IV Latin American Congress on Animal Nutrition, São Pedro, São Paulo, Brazil, pp. 7-8.

Wu, P., J-C. Tian, C. E. C. Walker, and F-C. Wang. 2009. Determination of phytic acid in cereals - A brief review. Int. J. Food Sci. Technol. 44:1671-1676. 